\title{
USIA EMAS ('GOLDEN-AGE'): MENYOAL KEPEDULIAN ORANGTUA TERHADAP PAUD

\author{
(Menyambut 'Kehadiran’ FKIP Prodi: PAUD di I-3, Batu, \\ Jawa Timur)
}

Yustus Adipati

\section{'Child-Centered': 'Child to day, Human tommorow'}

Menghadirkan 'Kampus PAUD' di tengah nuansa 'sekolah' teologi ('spiritual-balanced' with moral-integrity in God-centered values) dirasa 'sangat istimewa'. Terutama bila dilihat dari kebutuhan peran pendampingan gereja dalam Pendidikan Anak Usia Dini (PAUD) serta arus balik yang dihasilkannya, yang bernama: 'anak masa depan'.

Melalui motto: 'Child to day, Human tommorow' di masa 'GoldenAge' ini, diharapkan akan menjadi petunjuk menyangkut kesiapan seorang anak ('Child to day') serta kehidupannya di kemudian hari ('Human tommorow').

Laiknya sebuah 'Klinik' namun dengan 'nafas' teologi (Kristiani), kegiatan ini akan melewati serangkaian 'tes' serta 'uji-kepekaan' dalam menyiapkan kebutuhan anak menghadapi tantangan, berikut dampak negatif dari hasil kemajuan umat manusia. Dengan tujuan, agar anak memiliki tanggungjawab bagi dirinya sendiri (take care of the 'own' self), bagi orang lain (take care of the others) serta bagi semua makhluk di bumi (take care of the environment). Sehingga, sejak sebagai seorang anak sampai kelak di kemudian hari, tetap memiliki 'hidup' secara teologis (lihat Amsal 4:1-27; 6:20-23, bdk. Amsal 1:7; 9:10), maupun secara psiko-sosial yang 'sehat' dan 'berkualitas' (lihat Mazmur 111:10). Selain upaya 'tripatrit': Pemerintah, Gereja, dan Keluarga bagi kebutuhan anak di tahun awal usia 0-6 tahun dengan pendekatan anak secara utuh ('Child-Centered'). 


\section{Peran Pemerintah: in target}

Semua yang terkait perencanaan, proses pembelajaran, dan evaluasi penilaian hasil belajar merupakan bagian penting dari pendidikan. Pemahaman ini menjadi sangat penting, terutama untuk menyiapkan masa depan anak di kemudian hari. Menurut Undang-undang (UU) bahwa setiap anak berhak atas pendidikan dan pengajaran serta pengembangan pribadi dengan tingkat kecerdasan sesuai dengan minat dan bakatnya. Hal mana termaktub dalam UU No. 23 Tahun 2002 (dalam Direktorat Pendidikan Anak Usia Dini, Dirjen Pendidikan Luar sekolah dan Pemuda, DEPDIKNAS, 2002) tentang Perlindungan Anak disebutkan bahwa:

Setiap anak berhak untuk hidup, tumbuh, berkembang dan berpartisipasi secara wajar sesuai dengan harkat dan martabat kemanusiaan, serta mendapat perlindungan dari kekerasan dan diskriminasi”.

Dalam UU No. 20 tahun 2003 tentang Sistem Pendidikan Nasional dijelaskan bahwa:

Pendidikan anak usia dini adalah suatu upaya pembinaan yang ditujukan kepada anak sejak lahir sampai dengan usia enam tahun yang dilakuka melalui pemberian rangsangan pendidikan untuk membantu pertumbuhan dan perkembangan jasmani dan rohani agar anak memiliki kesiapan dalam memasuki pendidikan lebih lanjut.

Melihat tingkat usia anak, maka Pemerintah mencurahkan perhatian penuh terhadap pendidikan anak melalui PAUD. Saat ini, Pemerintah berupaya mendorong jumlah partisipasi anak dalam pelayanan PAUD. Sebagai data pembanding di tahun 2000, Fasli Jalal (KOMPAS, 18 Februari 2000) menuliskan bahwa:

Berdasarkan data tahun 2000, baru 17,39 \% dari total 12, 22 juta anak usia (4-6 tahun) yang mendapat pelayanan pendidikan. Sementara pada anak usia (0-6 tahun) yang menjadi sasaran program PAUD jumlah anak yang terlayani pendidikannya mencapai sekitar 17,9 juta dari total sekitar 26,09 juta anak. 


\begin{abstract}
Berdasarkan target APK (Angka Partisipasi Kasar) - PAUD 2014, berikut ini estimasi yang pernah dilakukan pemerintah, (http://pendidikananak2.blogspot.com/pendidikan-anak-usia-dini-paud.html), bahwa:
\end{abstract}

Pada tahun 2004 tercatat bahwa jumlah APK-PAUD baru mencapai 12,7 juta $(27 \%)$ dan tahun 2008 APK-PAUD telah mencapai 15,1 juta $(50,6 \%)$ serta diharapkan pada tahun 2009 akan mencapai 15,3 juta (53,6\%).

Melihat kondisi demikian, Pemerintah telah menetapkan rencana 5 (Lima) tahun ke depan APK-PAUD diharapkan mencapai 21,3 juta (72,6\%). Secara bertahap harapan untuk mencapai jumlah APK-PAUD tersebut terlihat pada tabel berikut ini.

Target Pendidikan Anak Usia Dini di Indonesia Tahun 2010 - 2014

\begin{tabular}{|c|c|c|c|c|c|}
\hline \multirow{2}{*}{$\begin{array}{l}\text { Target / } \\
\text { Sasaran }\end{array}$} & \multicolumn{5}{|c|}{ Tahun Pencapaian Target } \\
\hline & 2010 & 2011 & 2012 & 2013 & 2014 \\
\hline $\begin{array}{l}\text { Estimasi } \\
\text { Jumlah Anak } \\
\text { Usia 0-6 th }\end{array}$ & 30,18 juta & 30,2 Juta & 30,3 juta & 30,35 Juta & 30,4 Juta \\
\hline $\begin{array}{l}\text { Target } \\
\text { Sasaran } \\
\text { PAUD } \\
\text { (Formal \& } \\
\text { Nonformal) }\end{array}$ & $\begin{array}{l}\text { 17,4 Juta } \\
(57,8 \%)\end{array}$ & $\begin{array}{c}\text { 18,7 Juta } \\
(61,8 \%)\end{array}$ & $\begin{array}{l}19,9 \text { juta } \\
(65,7 \%)\end{array}$ & $\begin{array}{l}21 \text { Juta } \\
(69,3 \%)\end{array}$ & $\begin{array}{c}22,1 \text { Juta } \\
(72,6 \%)\end{array}$ \\
\hline $\begin{array}{l}\text { Target PAUD } \\
\text { Formal }\end{array}$ & $\begin{array}{l}5,8 \text { Juta } \\
(19,3 \%)\end{array}$ & $\begin{array}{l}5,85 \text { Juta } \\
(19,37 \%)\end{array}$ & $\begin{array}{l}5,9 \text { Juta } \\
(19,5 \%)\end{array}$ & $\begin{array}{l}5,95 \text { Juta } \\
(19,6 \%)\end{array}$ & 6 Juta $(19,7 \%)$ \\
\hline $\begin{array}{l}\text { Target PAUD } \\
\text { Nonformal }\end{array}$ & $\begin{array}{l}11,6 \text { Juta } \\
(38,5 \%)\end{array}$ & $\begin{array}{l}\text { 12,85 Juta } \\
(42,43 \%)\end{array}$ & $\begin{array}{l}14 \text { Juta } \\
(46,2 \%)\end{array}$ & $\begin{array}{l}\text { 15,05 Juta } \\
(49,7 \%)\end{array}$ & $\begin{array}{l}16,1 \text { Juta } \\
(52,9 \%)\end{array}$ \\
\hline
\end{tabular}




\section{Peran Gereja: in praxis}

Pada esensinya, Eka Darmaputera (1989: 115) mengatakan bahwa: "seluruh kegiatan gereja mengandung dimensi Pendidikan Agama Kristen (PAK)". Pengembangan seluruh potensi jemaat, terlebih pada anak usia dini merupakan fondasi penting bagi Gereja. Hal ini mengingatkan akan gagasan bahwa Gereja mengerjakan 2 (dua) fungsi, yakni: fungsi 'Pendidikan' dan fungsi 'Pekabaran injil'. Fungsi pertama, sebagai pertumbuhan ke dalam, berkenaan dengan kewajiban Gereja mendidik umat-Nya (Efesus 4:13-14) dan fungsi ke dua, sebagai pertumbuhan keluar berkenan dengan tanggungjawabnya dalam pemasyuran Injil ke seluruh dunia (Matius 28:19-20) (lihat Eli Tanya, 2006: 16). Namun, menurut Robert $R$ Boehlke (Wismoadi dalam Eli Tanya, 1999: 16, 84) bahwa dalam tugasnya Gereja tidak memberi tempat yang penting bagi pendidikan serta pengalaman belajar secara wajar untuk seluruh anggota gereja, terlebih pada peran sentral seorang Pendeta diharapkan agar dapat meningkatkan pelayanan paedagogisnya. Eli Tanya (2006: 78,82-83,88) mengatakan bahwa dalam mengelola pendidikannya, Gereja telah menetapkan struktur organisasi dengan membentuk semacam badan atau komisi yang menangani pelayanan anak, tanpa menyadari sungguhsungguh tentang siapa yang sesungguhnya paling berperan dan bertanggungjawab penuh untuk masa depan anak. Kerancuan praksis terhadap jenis pelayanan serta siapa yang bertanggungjawab secara paedagogis terhadap anak di dalam jemaat, salah satunya ialah tidak adanya keterpaduan antar kegiatan, termasuk program pendidikan di mana terdapat tumpang tindih penyelenggaraan antar badan atau komisi yang ada di dalam jemaat. Masingmasing kegiatan gereja seakan-akan terlepas satu dengan yang lainnya, serta tidak adanya badan khusus yang mengelola dan memiliki kapasitas yang jelas terhadap seluruh program pendidikan di jemaat. Pengembangan dan arah kebijakasanaan dalam pengangkatan pengurus atau pemimpin dan guru-guru Sekolah Minggu, penentuan jenis prioritas dan arah kebutuhan anggaran belanja untuk PAK, maupun perencanaan PAK dalam gereja, dsb., belum sepenuhnya dipahami secara memadai layaknya suatu kegiatan PAK yang ideal, serta terencana dari gereja selaku penanggungjawab penuh pendidikan iman kristiani, baik untuk pribadi maupun kelompok ( (Lih. Eli Tanya, 2006: 88). Termasuk dalam merespon isu-isu terbaru di luar institusi Gereja, seperti 
DEPDIKNAS. Misalnya, mengenai arah pembelajaran anak sebagaimana yang ditetapkan dalam acuan pembelajaran PAUD. (Lihat Direktorat Pendidikan Anak Dini, Usia, Menu Pembelajaran Generik, Dirjen Pendidikan dan Luar Sekolah, Departemen Pendidikan Nasional, 2002). Sehingga, selaku organisasi masyarakat keagamaan, Gereja diharapkan serius serta tanggap terhadap programnya dan upaya sosialisasi PAUD di internal jemaat melalui peran orangtua sebagai penanggungjawab lingkungan 'pendidikan' yang terdekat dan pertama kali, baik aspek fisik, intelektual, moral, emosi, dan kehidupan sosial anak (bdk. Ul.6: 6-9; 20-25). Di dalam keluargalah, seorang anak memperoleh pengalaman dan pengetahuannya sejak usia dini.

\section{Peran Keluarga: in reality}

Eksekutor utama terhadap kebijakan PAUD ada di tengah keluarga. Gautama (Kompas, 29 April 2002) mengatakan bahwa "sebenarnya menjadi tanggungjawab orangtua dan masyarakat serta tidak memerlukan campur tangan pemerintah". Sejak usia lahir sampai dengan memasuki pendidikan dasar, bagi seorang anak merupakan masa keemasan sekaligus masa kritis bagi pencapaian tumbuh kembang yang optimal. Pembentukan demikian berlangsung di dalam keluarga.

Menurut Torres (1996) ada beberapa elemen dalam pendidikan awal anak yang perlu mendapat perhatian. Pertama, kebutuhan anak akan pentingnya pengenalan diri melalui proses interaksi sosial dengan sesama; Ke dua, kebutuhan anak dalam pembentukan identitas melalui kehadiran dalam kelompok; Ke tiga, kebutuhan anak akan norma-norma serta nilai-nilai hidup dalam keluarga melalui kegiatan praktis kehidupan sehari-hari dalam ritme yang jelas dan teratur; Ke empat, kebutuhan anak bagi pengembangan jati diri. Itulah sebagian tugas para orangtua, agar ke depannya anak menjadi matang dan mandiri.

Para orangtua dapat mewujud-nyatakan masa usia emas ( 'Golden-Age') seorang anak agar efektif dan maksimal. Kepada para orangtua diharapkan cakap dan mampu mengambil peran di setiap pertimbangan atau putusannya terkait dengan masalah kebutuhan anak. Kemampuan dan kemahiran para orangtua ketika mengambil keputusan, menyiratkan adanya kepedulian 
terhadap tumbuh kembang anak, baik fisik, intelektual, kehidupan emosi maupun psikososialnya. Perhatian utama orangtua yang terpenting adalah kebutuhan asupan makanan dan minuman, perbaikan gizi, perlindungan kesehatan serta perkembangan psikososial anak, serta kebutuhan penunjang lainnya, seperti: pemilihan sarana belajar dan tempat bermain menjadi tanggungjawab kepedulian para orangtua terhadap PAUD.

\section{Kepedulian Orangtua terhadap PAUD, seperti apakah?}

Upaya optimal dari para orangtua di masa 'Golden-Age' akan menentukan terbentuknya keterampilan dasar serta tugas perkembangan lebih lanjut pada seorang anak. Periode ini merupakan masa yang tepat untuk meletakkan dasar-dasar pengembangan pada kemampuan fisik, bahasa, sosial ekonomi, konsep diri, seni, moral serta nilai-nilai agama. Sehingga, upaya untuk mengembangkan seluruh potensi anak di usia dini membutuhkan perhatian serius dari para orangtua maupun pendidik dalam 'mengawal' berlangsungnya proses tumbuh kembang anak. Montessori (dalam Wolf, 1980: 5) menyebutnya bahwa pada periode masa usia emas merupakan 'SensitivePeriods', bagi tumbuh kembang secara fisik, intelegensia maupun daya kreatif pada diri anak.

Terkait dengan kepeduliaan orangtua terhadap PAUD ini, maka akan dibahas lebih jauh mengenai pengertian keluarga, fungsi keluarga, pengertian kepedulian, PAUD dalam keluarga, faktor-faktor yang mempengaruhi PAUD dalam keluarga, serta peran serta orangtua dalam PAUD.

\section{Pengertiaan keluarga}

Sebagai unit terkecil dalam masyarakat, lembaga keluarga dibentuk oleh Allah (Kej. 2: 22-24; Mat.19:5 bdk. Ef.5: 22-33). Alkitab menjelaskan bahwa pada awal penciptaan, Allah menjadikan manusia: laki-laki dan perempuan (Mark.10:6). Sebagai ciptaan termulia, "manusia" dijadikannya serupa dengan gambarNya, yang kemudian memberkatinya agar bertambah banyak serta memberi kuasa atas semua yang diciptakan (Kej.1: 26-28). 
Sehingga, peran lembaga keluarga menjadi sangat sentral bagi terbentuknya masyarakat yang bertanggungjawab.

Dalam Undang-Undang (UU) No. 10 tahun 1992 dan Peraturan P no. 27 tahun 1994 menyebutkan bahwa keluarga adalah unit terkecil dalam masyarakat yang terdiri dari suami istri atau suami istri dan anaknya, atau ayah dan anaknya, atau ibu dan anaknya. Lebih lanjut, Sopater (1996: 1) menjelaskan bahwa anggota keluarga terdiri dari bapak dan/atau ibu dan juga anak yang menjadi tanggungannya. Secara lengkapnya, Burgess dan Locke (dalam Tapi Omas Ihromi, 1995: 5) menguraikan pengertiannya tentang keluarga, demikian:

"keluarga merupakan kesatuan dari jumlah orang yang saling berinteraksi dan berkomunikasi dalam rangka menjalankan peranan sosial sebagai suami, istri, ibu, bapak, anak-anak, anak perempuan, saudara lakilaki dan saudara perempuan".

Melalui beberapa uraian di atas, maka dapat dirangkum bahwa keluarga adalah suatu ikatan antara laki-laki dan perempuan dan/atau juga beserta anak yang menjadi tanggungannya, agar berfungsi sebagai lembaga sosial dari unit terkecil masyarakat, dengan adanya keterlibatan dari para anggota di dalamnya, yakni selaku warga masyarakat yang bertanggungjawab.

\section{Fungsi Keluarga}

Pengertian yang benar tentang keluarga merupakan hal yang sangat penting dan mendasar dalam mempersiapkan masa depan anak. Pemahaman orangtua khususnya tentang bagaimana fungsi keluarga menjadi penentu arah sekaligus juga maksud dan tujuan pendidikan anak usia dini agar terlaksana dengan baik. Tidaklah berlebihan jika kemudian, tanggungjawab pendidikan awal anak ini sangat bergantung sepenuhnya kepada keluarga. Menurut PP no. 21 tahun 1994 disebutkan fungsi keluarga. Fungsi-fungsi yang dimaksud, adalah: a) fungsi keagamaan, b) fungsi sosial budaya, c) fungsi cinta kasih, d) fungsi melindungi, e) fungsi reproduksi, f) fungsi sosial daan pendidikan, g) fungsi ekonomi, dan h) fungsi pembinaan lingkungan. 
Godde (dalam Soetarlinah Sukadi, 1998: 6) menjelaskan bahwa keluarga sebagai lembaga sosial, juga diberi tanggungjawab untuk mengubah warga yang dihasilkannya menjadi manusia angggota masyarakat. Sehingga, bila dilihat dari perannya sebagai lembaga sosial, fungsi keluarga di tengah masyarakat merupakan salah satu bentuk tanggungjawab bersama serta saling bergantung dan membutuhkan satu dengan lainnya selaku sesama anggota masyarakat.

"Keluarga adalah kelompok kecil masyarakat manusia. Sebagai anggota masyarakat, keluarga membutuhkan dukungan dari masyarakat yang luas dan banyak bergantung kepada masyarakat" (Soetarlinah Sukadji, 1988: 5).

Sebagai agen perubahan sosial, lembaga keluarga terutama berperan dalam penanaman nial-nilai hidup anak melalui adat istiadat, kebiasaan maupun aturan yang berlaku di masyarakat. Terkait dengan tugas ini, Soetarlinah Sukadji (1988: 5) menjelaskan 4 (empat) hal, ketika keluarga menjalankan fungsinya, yaitu: a) Melahirkan warga baru, b) Memelihara kebutuhan fisik anggota keluarga, c) Mempersiapkan anak untuk berperan sebagai warga masyarakat, dan d) Melakukan kontrol sosial.

Melalui pola tertentu serta praktik nyata aturan umum yang berlaku di luar rumah, kepada seorang anak diharapkan tidak akan mengalami benturan yang berarti terhadap nilai-nilai yang telah diikuti di dalam rumah. Murray (dalam A Muri Yunus 1986: 26) mengatakan bahwa "keluarga berfungsi meletakkan dasar pendidikan dan juga meletakkan kerangka berfikir yang dinamis kepada seorang anak". Proses yang demikian ini, sesungguhnya telah berlangsung lama dan telah ada sepanjang usia peradaban manusia. Lebih terperinci lagi, Borgadus (Titi H Roebyantho, dalam Danny I Yatim dan Irwanto, 1993: 86) menjelaskan prosesnya sebagai berikut:

"Melalui orangtua, anak menerima proses saat anak mulai belajar segala tata cara, aturan sosial, kepercayaan, kebiasaan, norma sosial, norma kesusilaan, dan lain-lain yang berlaku di masyarakat". 
Missio Ecclesiae, 2(2), Oktober 2013, 163-183

Dari uraian di atas, dipahami bahwa ketika seorang anak hadir di tengah keluarga, tanggungjawab dan kewajiban para orangtua adalah memberikan fungsinya secara maksimal, seperti: perlindungan, rasa aman, dan tenteram di masa tumbuh kembang anak sebagai bentuk kepedulian orangtua terhadap PAUD.

\section{Pengertian Kepedulian Orangtua}

Istilah kepedulian berasal dari akar kata peduli. Menurut Poerwadarminta (1976: 722) bahwa di akar kata peduli mengandung arti perhatian. Sehingga kepedulian berarti suatu sikap seseorang atau kelompok terhadap sesuatu, yang di dalamnya terdapat faktor atau unsur perhatian. Bagi Sumadi Suryadibrata (1984: 14), perhatian menunjukkan pada suatu bentuk pemusatan tenaga psikis yang tertuju kepada suatu obyek, sedangkan Totok Santoso (1988: 15) mengatakannya sebagai kegiatan dalam bentuk proses persepsi yang melibatkan pengalaman seseorang secara sadar pada suatu obyek tertentu. Dari istilah perhatian ini yang lebih menekankan pada kegiatan aspek psikisnya ketimbang pada aspek fisik, maka pengertian kepedulian lebih pada sikap seseorang atau kelompok yang bukan hanya menunjukkan aktivitas psikis semata, tetapi juga pada melibatkan aktivitas fisiknya. Akibatnya, kepedulian sebagai bentuk dan wujud perhatian yang dilakukan secara sadar dengan obyek yang jelas, akan terlihat dalam ungkapan-ungkapan dan/atau tindakan-tindakan yang konkrit dari orang-orang yang melakukannya. Sebagai orangtua, tindakan yang demikian ini langsung terlihat baik fisik maupun psikis melalui tindakan sadar dengan cara memperhatikan setiap kebutuhan anak di dalam keluarga. Melalui aksesnya di dalam keluarga, terbuka lebar kesempatan untuk mengembangkan secara maksimal segenap potensi anak melalui peran lingkungan yang baik bagi masa tumbuh kembangnya. Dengan demikian kepedulian adalah kecenderungan bertindak, yang dilakukan secara sadar oleh para orangtua terhadap pendidikan awal seiring dengan bertambahnya usia di masa tumbuh kembang, secara fisik, intelektual, emosi dan psikososial anak.

\section{PAUD dalam Lingkungan Keluarga}


Secara garis besar, seorang anak dibentuk dan dibesarkan di lingkungan yang saling berhubungan satu dengan yang lainnya, yakni: a) lingkungan keluarga, b) lingkungan sekolah, dan c) lingkungan masyarakat (Schneiders, 1988: 151). Melalui ketiga lingkungan tersebut, seorang anak belajar berbagai tanggungjawab, keterampilan dan juga dalam hal kemandirian. Kegagalan maupun keberhasilan seorang anak di kemudian hari sepenuhnya ada di pundak para orangtua. Siti Hidayati Amal (dalam Tapi Omas Ihromi, 1991: 51) mengatakan bahwa: "berkurangnya sumber pengetahuan anak, persoalannya terletak pada keluarga". Sehingga, kebutuhan anak dalam keluarga menjadi bagian yang utama bagi setiap target dan kegiatan yang diupayakan pemerintah melalui program PAUD.

\section{Program PAUD}

Tingkat kecerdasan anak, berlangsung antara usia $0-6$ tahun. Sebagai salah satu bentuk program PAUD pada jalur pendidikan luar sekolah dilaksanakan dalam bentuk kelompok bermain, penitipan anak, dan bentuk layanan pendidikan lainnya, seperti: dukungan pelayanan pendidikan bagi anak dan orangtua/ibu yang mengikuti kegiatan pada lembaga Bina Keluarga Balita (BKB), Posyandu, Sasana Anak, Taman Balita dan lainnya (Fasli Jalal, 2001). Lembaga keluarga merupakan salah satu penunjang bagi terlaksananya PAUD. Apabila, pemberian stimulasi atau rangsangan kepada anak di dalam keluarga sangat sedikit, atau bahkan sama sekali tidak memadai, dan ini dialami di masa tumbuh kembang anak, maka akan dapat mengakibatkan hilangnya peluang dan masa keemasan anak untuk berkembang secara maksimal. Oleh karena pemenuhan perkembangan yang maksimal pada usia dini ini menjadi prasyarat utama agar seorang anak tidak mengalami kesulitan ketika anak mengikuti jenjang lebih lanjut pada pendidikan formal di Sekolah Dasar. Kegiatan yang demikian ini hanya dapat dilakukan oleh para orangtua.

Menurut Fasli Jalal (2001) bahwa dalam misi program PAUD terdapat kegiatan perawataan kesehatan, pemberian gizi yang memadai dan juga pengembangan psikososial anak. Pengenalan terhadap periode usia anak ini sangat dibutuhkan oleh para orangtua. Pada masa tumbuh kembang di usia dini, seorang anak akan mengalami tahapan perkembangan dalam kemampuan 
dasar, perkembangan emosi, dan kemandirian, serta pada aspek psikomotoriknya.

\section{Periode Usia 0 - 6 Tahun sebagai 'Sensitive-Period'}

Masa ini disebut "Sensitive-Period". Pada periode ini seorang anak membutuhkan perkembangan, seperti: koordinasi motorik, bahasa, tata tertib, ketajaman panca indera, tanggungjawab sosial, sopan santun, serta perkembangan dalam memahami perintah (verbal) atau ketika mempelajari gerakan pada anggota tubuh (fisik) (Torres, 1996). Montessori (Torres, 1996) membaginya ke dalam 2 (dua) tahapan perkembangan, yakni: perkembangan di tahap usia $0-3$ tahun dan perkembangan di tahap usia $3-6$ tahun.

\section{Tahapan "unconcious absorbent-mind" (usia 0 - 3 tahun)}

Ciri penting dalam tahapan ini ('unknowing, unwilling and effortless fashion'), adalah pembelajaran anak yang terjadi melalui penyerapan oleh pikiran yang berlangsung oleh karena: rasa keingin-tahuan, kemauan atau keinginan terhadap sesuatu "tanpa disadari". Proses ini ditandai, oleh:

1) Perkembangan pada organ tubuh. Sebagian pertumbuhan anggota tubuh terjadi di usia 2 (dua) tahun dengan terjadinya pertambahan pada berat badan.

2) Perkembangan koordinasi motorik. Seorang anak melakukan orientasi sensorial pada obyek tertentu, kemudian menyentuhnya dengan cara menggunakan mulut, tangan, serta kemampuan dalam penyesuaian keseimbangan sampai pada taraf keadaan yang terkontrol sempurna ("Balance and Equilibrium").

3) Pertumbuhan gigi. Perkembangan ini dibarengi dengan berfungsinya sistem pencernaan secara sempurna, mulai dari yang paling sederhana, yakni dalam pola meyusui sampai dengan mengkonsumsi jenis makanan yang berbeda dan beragam.

4) Perkembangan visual dan auditori.

5) Perkembangan Bahasa. Pada tahapan ini, seorang anak memulainya dari kondisi mendengar sampai berbicara dalam kalimat utuh. 
6) Aturan atau Tata Tertib. Pada awalnya, pengalaman anak hanya sesaat dan pada hal-hal tertentu saja ("temporal and special"). Hal ini sangat bergantung pada kelekatan yang kuat antara si anak dengan suasana rumah dalam keluarga. Pengalaman demikian menciptakan pola penyesuaian diri anak terhadap lingkungan sosialnya di kemudian hari. Seorang anak memulainya dengan melakukan kegiatan eksplorasi melalui kemampuan sensorialnya yang tajam.

\section{Tahapan "conscious absorbent-mind" (uisa 3 - 6 tahun)}

Ciri penting dalam tahapan ini, adalah pembelajaran anak yang terjadi melalui penyerapan oleh pikiran yang berlangsung "dengan disadari".

Pada tahapan ini, seorang anak sudah menyadari atau mempunyai alasan untuk melakukannya. Kesadaran anak dalam melakukan sesuatu kegiatan adalah karena alasan suka dan juga anak menikmatinya ("by pleasure and love"). Pada tahapan ini, seorang anak juga memperlihatkan apa dan siapa dirinya dan juga kemandiriannya. Dalam prosesnya, kegiatan ini ditandai melalui:

1) Pertumbuhan fisik yang terus berkembang. Sekalipun pertumbuhan ini berlangsung perlahan, namun cepat berlangsung pada usia 4 (empat) tahun.

2) Kemajuan dalam perkembangan kontrol motorik. Pada tahapan ini, keseimbangan gerakan anggota tubuh anak mencapai titik kelenturan tertentu.

3) Perkembangan dalam hal bersosialisasi. Dalam pencapaian ini, seorang anak telah siap untuk bermain dan bersosialisasi di lingkungan luar rumah.

4) Perkembangan yang sudah berpikir ke arah abstrak. Pada tahap ini, misalnya seorang anak dapat memahami ide tentang adanya "kursi" tanpa melihat keberadaan bendanya atau obyeknya secara langsung. Pada tahapan ini anak juga dapat memahami dalam bentuk berpikir secara generalis. Di dalam kehidupan nyata sehari-hari, seorang anak sudah memahami suatu peristiwa yang terjadi, misalnya bila seseorang itu pergi, seseorang itu juga pasti akan kembali. 
5) Perkembangan dalam hal kemampuan tulis menulis dan membaca. Kemampuan demikian ini, seiring dengan perkembangan pada keterampilan motorik halus ketika anak akan menggunakan alat tulis.

Dengan demikian, jelas bahwa keluarga merupakan lingkungan belajar yang terpenting bagi anak pada masa perkembangannya, baik fisik, intelektual, emosi, maupun psikososial anak seiring dengan faktor-faktor yang mempengaruhinya.

\section{Faktor-faktor yang mempengaruhi PAUD}

Agar dapat tumbuh kembang secara maksimal, maka seorang anak membutuhkan di antaranya adalah pengalaman hidup praktis sehari-hari ('Practical Life'). Seorang anak menerima pengetahuan dan pendidikan awalnya untuk pertama kali adalah di dalam keluarga. Montessori (1870-1952) mengatakan bahwa di masa tahun-tahun awal, seorang anak mengalami periode atau masa 'Absorbent-Mind', yakni: kemampuan dalam menyerap berbagai informasi sebanyak-banyaknya sesuai dengan kebutuhan yang di rasa anak saat itu (dalam Hainstock, 1999: 18). Bagi seorang anak agar tumbuh kembangnya berlangsung secara maksimal, membutuhkan sarana dan prasarana pendukung 'pendidikan' yang tepat di dalam keluarga. Siti Hidayati Amal (dalam Tapi Omas Ihromi, 1990, 51) mengatakan bahwa "berkurangnya sumber pengetahuan bagi anak, persoalannya terletak pada keluarga". Menurut Sastrapratedja (dalam Kaswardi, 1993: 4) mengatakan bahwa proses yang ditempuh oleh seorang anak, mulai dari: a) memilih (segi kognitif), b) menghargai (segi afektif), c) bertindak (segi psiko-motor), d) membentuk pola, e) menjadi prinsip, pegangan atau norma hidup bagi diri anak.

Aktivitas pembelajaran anak di dalam keluarga juga membutuhkan proses sosialisasi (Soejono Soekanto, 1984: 140). Salah satu nilai tambah dan penunjang penting untuk meningkatkan kemampuan sosialisasi anak adalah peran komunikasi antara orangtua dan anak. Lubis (2002) mengingatkan hal terpenting dalam berkomunikasi dengan anak, bahwa memberitahu tangis dan tawa sama pentingnya dan sama dapat diterima. Lubis (dalam KOMPAS, 18 Juli 2002) mengatakan: "bagi anak yang sedang tumbuh kembang, ia merasa 
enak dan lega bila ia merasa kemarahaan atau kesedihannya dapat diterima orangtua".

Selanjutnya, dampak dari kemampuan bersosialisasi ini, menurut Schneiders (1964: 452-453) akan terlihat bagaimana seorang anak: a) memiliki hubungan yang akrab dengan/di antara anggota keluarga, b) mau menerima otoritas orangtua, c) mampu bertanggungjawab dan menerima aturan, d) mampu bekerja kelompok atau individual, e) menghargai kesamaan derajat dan kemandirian. Sehingga, menurut Schneiders (1988: 122) bahwa unsur-unsur pendukung dalam keluarga yang dimaksud adalah: a) faktor fisiologis, b) faktor kematangan, c) proses perkembangan, d) kondisi psikologis, dan juga e) faktor lingkungan, seperti: kebiasan-kebiasaan, adaptasi, adat istiadat dan juga aturan dalam kehidupan keagamaan. Para ahli lainnya, Maliphant dan Wright (dalam Harre dan Lamb, 1986: 206-208) mengatakan bahwa faktor-faktor tersebut, adalah: a) kesehatan fisik, b) jenis makanan yang dikonsumsi ('Nutrient'), c) bawaan genetik ('Genetic Endowment'), d) tekanan-tekanan emosi, e) pengaruh konflik dalam keluarga. Sementara itu, A Mudzakir dan Joko Sutrisno (1995: 161) menyebutkan ketergantungan pelaksanaan PAUD pada: a) keadaan ekonomi keluarga, b) tingkat kemampuan orangtua dalam merawat anak, c) tingkat pendidikan orangtua, d) suasana keluarga, e) cara mendidik anak, dan e) hubungan antara orangtua dengan anak.

Dari uraian di atas, maka dapat dirangkum beberapa faktor yang mempengaruhi PAUD di dalam keluarga, yaitu: a) latar belakang falsafah/nilai-nilai yang dianut dalam kehidupan orangtua, b) bentuk kasih sayang antara orangtua dan anak, c) cara berkomunikasi antara orangtua dan anak, d) wawasan pendidikan orangtua, e) keadaan sosial dan ekonomi keluarga, f) terpenuhinya kebutuhan anak akan rasa aman dan tenteram.

\section{Peranserta Orangtua dalam PAUD}

Seorang anak memiliki waktu yang panjang untuk beraktivitas dan berinteraksi di tengah keluarga. Oleh karenanya, urusan pendidikan awal anak tidak sepenuhnya diserahkan sebagai tanggungjawab pemerintah atau lembaga pendidikan formal seperti sekolah. A Samana (1992: 11) mengatakan bahwa "orangtua mempunyai peran dan hak mendidik yang paling asasi (bersifat 
kodrati, pertama dan utama)". Fasli Jalal (KOMPAS, 18 Februari 2002) mengemukakan bahwa berkaitan dengan aktivitas PAUD dalam keluarga, tugas dan tanggungjawab dari para orangtua, mencakup 3 (tiga) hal penting, yaitu: a) perbaikan gizi; b) perlindungan kesehatan; c) stimulasi psikososial. Diharapkan bahwa perkembangan di aspek fisik, intelektual, dan emosi serta psikososial anak sudah berlangsung di dalam keluarga. Schneiders (1964: 6467) menjelaskan bahwa ada beberapa hal yang harus diperhatikan oleh para orangtua untuk tumbuh kembang anak menjadi maksimal. Hal-hal yang dimaksudkan Schneiders, yaitu: a) 'skill anak', b) pola belajar, dan c) pola respon anak dalam mengatasi konflik.

Hal-hal berikut ini yang harus diperhatikan oleh para orangtua bagi tumbuh kembang anak yang dimaksudkan beserta dengan uraiannya:

1) Skill Anak: Bentuk keterampilan dasar yang diisyaratkan bagi kesiapan anak untuk memasuki sekolah formal adalah pada kemampuan dasar membaca, menulis, dan berhitung. Dalam menunjang proses pembentukan skill anak dibutuhkan perhatian para orangtua, berupa gejala yang positif maupun hal yang negatif, seperti: kesehatan fisik serta jenis makanan yang dikonsumsi anak, kegiatannya dimulai dari pemeriksaan rutin ke dokter, tambahan asupan gizi, sampai kepada pemberian vitamin dan kebutuhan penting lainnya. Menurut Khudori (KOMPAS, 25 Agustus 2003) bahwa "masalah gizi yang parah pada usia muda akan menghambat laju tumbuh kembang fisik anak, perkembangan kecerdasan, dan penyakit generatif'. Dalam pertumbuhan fisik, misalnya seorang anak membutuhkan dukungan serta perhatian pada perbaikan gizi dengan asupan nutrisi yang memadai sesuai dengan bertambahnya usia dan tingkat kebutuhan sesuai usia perkembangannya. Menurut Faiqoh (warta plus/vol. 20/no. 2/Desember 2001) bahwa "ketidakpastian anak memasuki pendidikan dasar, antara lain disebabkan kurangnya intervensi pendidikan, kesehatan, dan gizi pada saat anak usia dini". Apalagi, pada saat pemenuhan kebutuhan tumbuh kembangnya, seorang anak sedang mengalami proses pertumbuhan otak atau kemampuan kecerdasan. Gautama (KOMPAS, 29 April 2002) menyatakan bahwa "tanpa keseimbangan pelayanan kesehatan dan gizi anak, sulit diharapkan keberhasilannya. Apalagi perkembangan otak anak sebagian besar terjadi pada usia dini". Sehingga, dapat dipahami bahwa sebagai penunjang untuk pembentukan 'Skill Anak' dibutuhkan peran para orangtua, mulai dari menyiapkan kebutuhan-kebutuhan vital anak, seperti: 
perhatian terhadap sarana penunjang bagi kesehatan fisik anak; kemudian, pemenuhan kebutuhan gizi anak melalui makan dan minuman yang sehat, serta kebutuhan vitamin, sampai kepada pemenuhan kebutuhan asupan-asupan penunjang lainnya.

2) Pola Belajar Anak: Pemberian stimulasi sosial terhadap anak membutuhkan waktu, konsistensi serta keteraturan. Pembiasaan belajar menjadi 'Daily Habit' yang maksimal dipraktikkan anak di tengah keluarga. Hal-hal yang terkait dengan hubungan orangtua dan anak aturan yang diterapkan di dalam keluarga. Hurlock (1973: 170-173) menjelaskan bahwa:

"Hubungan anak dalam keluarga berdampak pada sikap anak terhadap sekolah, penyesuaian diri, pola peran, metode pelatihan terhadap anak, peran seks, cita-cita dan prestasi anak, kreativitas, serta kepribadian anak"

Para orangtua memiliki peran yang penting ketika memberikan dukungan maupun rangsangan bagi tumbuh kembang anak, agar mencapai tingkat kesiapan yang memadai dalam tugas perkembangan selanjutnya. Berkaitan dengan upaya orangtua terhadap stimulasi, sarana dan prasarana terhadap tumbuh kembangnya seorang anak, Piaget (dalam Singgih Gunarsa, 1997: 162), menjelaskan bahwa:

"tugas para orangtua atau pendidik bukan memberi pengetahuan, akan tetapi tugasnya ialah mencarikan, menempatkan, memberikan alat-alat, atau cara cara yang menimbulkan minat, agar anak terangsang untuk memecahkan atau mengatasi persoalannya sendiri"

Ketika seorang anak memasuki jenjang pendidikan formal, Greeberg (1989, Faiqoh dalam Warta plus/vol.20/No.2/Desember 2001) mengatakan bahwa "keterlibatan orangtua di sekolah meringankan guru dalam membina kepercayaan diri anak, mengurangi masalah disiplin anak, dan meningkatkan motivasi anak". Dalam menciptakan antusiasme belajar, Gruinsburg dan Opper (dalam Singgih D Gunarsa, 1997: 163) mengingatkan bahwa:

"sesungguhnya, orangtua atau pendidik itu belajar dari anak dan diarahkan oleh anak-anak. Sehingga, perlu kepekaan dan keluwesan dari 
pihak orangtua atau pendidik agar kebutuhan anak dan rasa ingin tahu pada diri anak dapat tersalur dengan baik"

Agar pelaksanaan program PAUD di tengah keluarga berjalan baik, Blom (Wolf, dalam Gage dan Barliner, 1984: 116) menyebutkan beberapa peran orangtua, yaitu: a) memberikan motivasi berprestasi, b) menstimulasi pengembangan bahasa, c) menciptakan kesempatan anak dapat belajar di rumah maupun di luar rumah.

Dari uraian di atas, diperoleh gambaran bahwa terbentuknya pola belajar anak, agar tumbuh kembang menjadi maksimal, dibutuhkan partisipasi nyata para orangtua, mulai dari pemberian rangsangan, fasilitas sarana dan prasarana belajar seperti alat bermain anak, sampai kepada kebutuhan akan rasa keingin-tahuan melalui antusiasme berbagai aktivitas pembiasaan belajar anak agar menjadi 'Daily Habit'.

3) Respon Anak dalam Mengatasi Konflik: Seorang anak perlu belajar berinteraksi dengan lingkungan di sekitarnya. Hal ini dilakukan untuk ajang praktik berbagai keterampilan yang pernah dilakukan dan yang diperolehnya dari dalam lingkungan pertamanya, yakni lingkungan keluarga. Tujuannya adalah agar anak mempunyai pengalaman belajar, terutama dengan orang lain ketika memperluas lingkungan belajarnya. Mengenai kegiatan ini, Bernard (dalam A A Schneiders, 1964: 455) menjelaskan lebih jauh sebagai berikut:

"modal dasar dalam beradaptasi di kehidupan sosial adalah sikap menolong, pengertian, simpati, kemandirian, perhatian yang lebih, kemampuan bercakap-cakap, dan penampilan kepribadian yang menarik"

Agar terampil dan terasah di kehidupan sosialnya yang baru, seorang anak membutuhkan peran pendamping yang tepat dari para orangtua; terutama perannya selaku ayah maupun ibu. Pada titik ini seorang anak dapat mencurahkan isi hati kepada orangtua, terutama sekali ketika menghadapi konflik. Menurut, Titi H Roebyantho (dalam Danny I Yatim dan Irwanto, 1993: 86) bahwa peran seorang ayah, di antaranya: a) sumber kekuatan dasar identifikasi, b) penghubung dunia luar, c) pelindung terhadap ancaman, d) pendidikan, disiplin, tanggungjawab, dan lain-lain. Sedangkan, peran seorang 
ibu, diantaranya: a) memberi kasih sayang, b) tempat mencurahkan hati, c) mengatur rumah tangga. Pada umumnya, respon terhadap peran para orangtua ini, diungkapkan melalui beberapa pengalaman yang dialami anak, seperti: pelukan, ciuman, kata-kata sayang dan perasaan senang lainnya secara langsung dan nyata (Stans Ismail, dalam Andar Ismail, 1999: 170). Melalui sarana yang dibangun di dalam keluarga ini, seorang anak akan mempelajari pelbagai aturan atau norma yang berlaku, baik yang ada di dalam keluarga maupun yang ada di dalam masyarakat. Seorang anak mempelajari kaidahkaidah yang berlaku di dalam masyarakat, mengenal cara-cara untuk mengatasi konflik. Beberapa pengetahuan yang wajib diperoleh anak melalui peran pendampingan dari para orangtua, menurut Gauthy (dalam Kaswadi, 1993: 116-127) adalah: a) menghargai dan menerima anak secara baik, b) menerima perbedaan-perbedaan, c) mendahulukan kepentingan orang lain, d) meningkatkan dialog, e) bekerja dan bermain dalam tim, f) bertindak adil dalam hubungan dengan anak, g) menghargai janji, h) melaksanakan tugas panggilan, i) menghargai kekuasaan yang benar, j) menghargai dan mengusahakan perbaikan lingkungan, k) melibatkan diri dalam kelompok/partisipasi, 1) menghayati kehidupan komunitas, m) menaruh perhatian dan berperan serta dalam masalah-masalah dunia, n) berdoa bersama.

Salah satunya adalah konflik dalam persaingan. Ketika seorang anak tidak dapat menghindari dari keadaan tersebut, Stans Ismail (1999: 184) menjelaskan beberapa peran dari para orangtua, di antaranya: a) mengajarkan anak untuk bersikap adil. Misalnya menunggu giliran dan membagi sumber yang terbatas. Berarti semua orang menerima apa yang menjadi haknya, b) mengajarkan anak bersikap sportif. Misalnya anak perlu mengerti dengan baik bahwa musuh sesungguhnya dalam setiap pertandingan adalah dirinya sendiri, c) mengajarkan anak untuk bersikap sebagai 'Good Looser' (kalah terhormat). Misalnya kalah terhormat berarti dapat menghargai anak yang menang, dapat melihat sifat kuat lawan dan dapat mengakui kekurangan dirinya.

\section{Rangkuman}

Berdasarkan berbagai penjelasan berkenan dengan kepedulian orangtua terhadap PAUD, maka beberapa faktor disebutkan sebagai berikut: 
a) Fakfor 'Skill Anak': Memberikan perhatian seperti sarana penunjang bagi kesehatan fisik anak; pemenuhan kebutuhan gizi anak melalui makan dan minuman yang sehat, serta kebutuhan vitamin, sampai kepada pemenuhan kebutuhan asupan-asupan penunjang lainnya.

b) Faktor Pola Belajar Anak: Memberikan perhatian berupa kebutuhan fasilitas sarana prasarana belajar, seperti alat bermain anak untuk membangun antusiasme serta rasa keingin-tahuan anak, dengan berkesinambungan, konsistensi, keteraturan agar pembiasaan belajar itu menjadi 'Daily Habit' anak.

c) Faktor Respon Anak dalam Mengatasi Konflik: Memberikan pengalaman mencurahkan isi hati anak kepada orangtua; menempatkan diri di tengah persaingan, serta mempelajari pelbagai aturan atau norma yang berlaku.

Melalui penjelasan di atas, dapat dirangkum beberapa indikator mengenai Kepedulian orangtua terhadap PAUD, sebagai berikut:

1) Faktor 'Skill Anak', dengan indikator-indikatornya, meliputi: a) Kesehatan Fisik, b) Kebutuhan Gizi.

2) Faktor Pola Belajar Anak, dengan indikator-indikatornya, meliputi: a) Fasilitas Belajar, b) Fasilitas bermain, c) Kebiasaan belajar.

3) Faktor Respon Anak dalam Mengatasi Konflik, dengan indikatorindikatornya, meliputi: a) Pencurahan hati, b) Persainan, c) aturan.

Proficiat I-3, atas dibukanya FKIP Prodi: PAUD!. Kemuliaan hanya 'dari dan oleh serta bagi Tuhan untuk selama-lamanya!

\section{REFERENSI}

(1963), (1980), Alkitab. Jakarta: Lembaga Alkitab Indonesia. Faiqoh,

2001 Strategi Peningkatan Kualitas Anak Dini Usia, warta Plus/vol.20/No.2/Desember 2001

Gunarsa, Singgih D. 
1977 Psikologi Perkembangan. Jakarta, BPK Gunung Mulia

Hainstock, E. G.,

1999 Metode Pengajaran Montessori untuk Anak Pra-sekolah. Jakarta: Pustaka Delapratasa.

(http://pendidikananak2.blogspot.com/pendidikan-anak-usia-dini-paud.html).

Hurlock, Elizabeth B.,

1993 Psikologi Perkembangan. Jakarta: Penerbit Erlangga.

Ismail, Andar (Penyunting),

1999 Ajarlah Mereka Melakukan. Jakarta: BPK Gunung Mulia

Ihromi, Tapi Omas (Penyunting)

1990 Para Ibu yang Berperan Tunggal dan yang Berperan Ganda. Jakarta: Lembaga Penerbit Fakulata Ekonomi UI

Jalal, Fasli

2001 Kebijakan mendesak PLSP Otonomi Daerah, Desentralisasi Pendidikan, Warta Plus/vol.20/No.2/Desember 2001

Kaswardi, EM K (Penyunting),

1999 Pendidikan Nilai Memasuki Tahun 2000. Jakarta, Grasindo

$\mathrm{KOMPAS}_{2}$ Senin, 18 Pebruari 2002, Senin, 29 April 2002, Senin, 25 Agustus 2003

2005 Pendidikan Anak Usia Dini, Mengapa dan Bagaimana. Jakarta: LAI

Montessori, Maria

1965 The Four Plane of Education. Newport: st. Leo league.

Montessori, Maria

1973 To Educate The Human Potential. Madras:Kalakshetra

Mudzakir, A, dan Joko Sutrisno,

1982 Psikologi Pendidikan. Jakarta: Rineksa Cipta

Perwadarminta, W.J.S.

1976 Kamus Besar Bahasa Indonesia. Jakarta: Balai Pustaka

Room, Harre and Lamb, Roger

1986 The Dictionary of Developmental and Educational Psychology. Massachusetts: MIT Press

Santoso, Totok

1988 Layanan Bimbingan Belajar di Sekolah Menengah. Salatiga:

Schneiders, A. A. 
1964 Personal Adjustment and Mental Health. New York: Holt, Rinehart, and Wilson

Samana, A.

1991 Sistem Pengajaran. Yogyakarta: Kanisius

Sukadji, Soetarlinah

1988 Keluarga dan Keberhasilan Pendidikan. Jakarta, Urusan Produksi dan Distribusi Alat Tes Fakultas Psikologi UI

Soekanto, Soerjono

1984 Teori Sosiologi. cet. II.. Jakarta: Ghalia Indoneia

Sopater, Soelarso

1996 Peranan dan Tanggungjawab Keluarga dalam Pendidikan Anak. Jakarta: Badan pertimbangan Pendidikan nasional

Tanya, Eli

2006 Gereja dan Pendidikan Agama Kristen. Cianjur: Penerbit STTC

Torres, Jaime

1996 Seminar Presentation. Jakarta: Open-House TK/SD PSKD Montessori

Torres, Jaime,

t.t. $\quad$ The Four Plane of Development and The Montessori Method. Canada: Toronto Montessori Center

UU RI No. 20

2003 Sistem Pendidikan Nasional. PT Kloang Klede Putra Timur bekerjasama dengan Koperasi Primer Praja Mukti I Depdagri.

Wolf, A. D.,

1980 A Parent's Guide to Montessori Classroom. Penn-Mont: Academy

Yunus, A.Muri

1982 Pengantar Ilmu Pendidikan. Jakarta: Ghalia Indonesia

Yatim, Danny I dan Irwato

1993 Kepribadian, Keluarga, dan Narkoba. Jakarta, Penerbit Arcan 